\title{
ANALISIS SURVIVAL SUHU TUBUH PADA PASIEN PNEUMONIA YANG DIBERIKAN VITAMIN D
}

\section{Arief Rafsanjani ${ }^{1 *}$ Endang Darmawan ${ }^{2}$ Nurcholid Umam Kurniawan ${ }^{3}$}

\author{
"Mahasiswa Program Pascasarjana, Fakultas Farmasi, Universitas Ahmad Dahlan Yogyakarta, \\ DIY, Indonesia, ${ }^{2}$ Fakultas Farmasi, Universitas Ahmad Dahlan Yogyakarta, DIY, Indonesia, \\ ${ }^{3}$ Fakultas Kedokteran, Universitas Ahmad Dahlan Yogyakarta, DIY, Indonesia.
}

E-mail: endang.darmawan@pharm.uad.ac.id

\begin{abstract}
Abstrak
Pneumonia disebabkan karena adanya infeksi pada paru-paru sehingga perlu di berikan antibiotik untuk penatalaksanaannya. Pemberian terapi kombinasi antibiotik memberikan hasil yang cukup bagus pada beberapa kasus, namun masalah angka mortalitas yang terjadi masih tinggi, maka perlu diberikan terapi tambahan (terapi adjuvant) untuk meningkatkan angka kesembuhan pasien. Salah satu terapi adjuvant yang bisa di berikan yaitu vitamin D. Vitamin D di ketahui berperan dalam fungsi pertahanan tubuh, baik dalam imunitas alamiah dan adaptif serta berperan dalam pertahanan tubuh pada kasus infeksi, alergi, keganasan, dan autoimun.Penelitian ini adalah penelitian eksperimental Double Blind Randomised Clinical Trial. Subyek penelitian adalah pasien anak usia 6 bulan sampai 5 tahun yang terbagi menjadi dua kelompok perlakuan, yaitu kelompok intervensi $(n=35)$ dan kelompok kontrol $(n=35)$. Kelompok intervensi mendapatkan vitamin $D$, sedangkan kelompok kontrol sebagai plasebo. Data yang diambil yaitu variable terikat berupa luaran terapi yang meliputi hasil pemeriksaan suhu tubuh. Hasil penelitian ini menunjukkan bahwa vitamin $\mathrm{D}$ mampu memberikan peluang ketahanan hidup di hari ke tiga setelah pemberian vitamin D.
\end{abstract}

Kata Kunci: Vitamin D, Plasebo, Suhu Tubuh 


\begin{abstract}
Pneumonia is caused due to an infection in the lungs so antibiotics need to be administered for its management. Giving antibiotic combination therapy gives pretty good results in some cases, but the problem of mortality rates that occur is still high, it is necessary to be given additional therapy to increase the patients cure rate. One of the adjuvant therapies that can be given is vitamin $\mathrm{D}$. vitamin $D$ is know to play a role in the body's defense function, both in natural and adaptive immunity and plays a role in the body's defense in cases of infections, allergies, malignancies, and autoimmune. This research was an experimental Double-Blind Randomized Clinical Trial. The study subjects were pediatric patients aged six months to 18 years who were divided into two groups, namely the intervention group $(n=35)$ and the control group $(n=35)$. The intervention group received vitamin $\mathrm{D}$, while the control group received a placebo. Data observed were body temperature. This study aimed to determine the effectiveness of vitamin $D$ based on the parameters of fever in pediatric patients with pneumonia infections treated at the Muhammadiyah Bantul Hospital. The results of this study prove that vitamin $D$ is able to provide a chance of survival on the third day after administration of vitamin D
\end{abstract}

Keywords: Vitamin D, Placebo, Body Temperature

\title{
PENDAHULUAN
}

Pneumonia merupakan infeksi akut pada paru-paru yang disebabkan oleh bakteri dan virus seperti Streptococcus pneumonia, Haemophilus influenza tipe b (Hib), dan virus pernapasan syncytial (RSV) [1]. Pneumonia menjadi penyebab utama kematian pada anakanak usia di bawah 5 tahun dan berkontribusi hingga $14 \%$ dari total kematian anak secara global pada tahun 2013 [2]. Prevalensi kematian yang disebabkan oleh pneumonia pada tahun 2000 mencapai 1,8 juta dan mengalami penurunan menjadi 900.000 pada tahun 2013. Meskipun sudah ada penurunan mortalitas, pneumonia tetap menjadi penyebab kematian tunggal pada anak-anak di luar periode neonatal sekitar 900.000 dari perkiraan 6,3 juta kematian anak pada tahun 2013 [3].

Pemberian terapi kombinasi antibiotik memberikan hasil yang cukup bagus pada beberapa kasus, namun masalah angka mortalitas yang terjadi masih tinggi, maka perlu diberikan terapi tambahan (terapi adjuvant) untuk meningkatkan angka kesembuhan pasien. Salah satu terapi adjuvant yang bisa di berikan yaitu vitamin D. Vitamin D di ketahui berperan dalam fungsi pertahanan tubuh, baik dalam imunitas alamiah dan adaptif [4] serta berperan dalam pertahanan tubuh pada kasus infeksi, alergi, keganasan, dan autoimun [5]. Oleh sebab itu Peneliti tertarik melakukan penelitian tentang survival analisis suhu tubuh pasien pneumonia yang diberikan vitamin $D$ di Rumah Sakit PKU Muhammadiyah Bantul.

\section{METODOLOGI}

\section{Alat dan bahan}

Obat yang digunakan pada penelitian ini adalah Vitamin D (D3-VIT®), $400 \mathrm{Ul} / 5 \mathrm{ml}$, Industri Farmasi PT Gracia Pharmindo). Dosis yang digunakan dalam penelitian tergantung usia pasien, 6-12 bulan mendapatkan dosis $400 \mathrm{UI}$ sekali sehari dan 12 bulan - 18 tahun mendapatkan dosis $600 \mathrm{UI}$ sekali sehari. Pasien mendapatkan obat setelah mendapatkan resep 
dari dokter sesuai dengan dosis yang sudah di tentukan, pemberian obat ini dilakukan sekali sehari pada jam yang sama.

\section{Metode Penelitian}

Penelitian ini menggunakan desain penelitian eksperimental Double Blind Randomised Clinical Trial. Subyek penelitian adalah pasien anak usia 6 bulan sampai 18 tahun yang menderita pneumonia (ICD-10: J18.9) di Rumah Sakit PKU Muhammadiyah Bantul. Pengambilan data dilakukan sampai mendapatkan 70 pasien yang berlangsung pada bulan maret-juli 2019. Penelitian ini di bagi dalam dua kelompok, kelompok perlakuan mendapatkan vitamin $D(n=35)$ dan kelompok kontrol mendapatkan plasebo $(n=35)$. Kriteria inklusi pada penelitian ini adalah pasien anak berusia 6 bulan sampai 18 tahun, terdiagnosa pneumonia, mendapatkan vitamin $\mathrm{D}$ dan wali pasien bersedia mengisi lembar informed consent. Kriteria eksklusi dimana pasien tidak mendapatkan resep vitamin $\mathrm{D}$ dan pasien anak pulang paksa atau di rujuk ke rumah sakit yang lain. Setelah pasien masuk dalam kriteria inklusi dan mendapatkan vitamin D atau plasebo, selanjutkan dilakukan pemantauan dan pengambilan data klinis pasien selama di rawat di rumah sakit.

\section{Karakteristik}

Karakteristik demografi jenis kelamin subjek pada penelitian ini terdiri dari 35 pasien anak laki-laki dan 35 pasien anak perempuan. Penelitian demografi yang dilakukan oleh Refrensi [6] pada pasien balita di Indonesia yang menderita pneumonia pada anak laki-laki danperempuan memiliki jumlah yang hampir sama. Jumlah pasien laki-laki ditemukan sebanyak 41.925 dan pasien perempuan sebanyak 40.695. profil kesehatan tahun 2017 kabupaten Bantul melaporkan bahwa bahwa pada tahun 2017 kasus pneumonia balita lakilaki lebih banyak dibandingkan perempuan yaitu 701 kasus dan pasien balita perempuan berjumlah 496 orang [7]. Berikut merupakan grafik estimasi tahan hidup pasien anak pneumonia yang dirawat di bangsal pediatrik PKU Muhammadiyah Bantul setelah diberikan vitamin $\mathrm{D}$ dan plasebo menggunakan metode Kaplan-Meier. hasil analisis survival kaplan meier bisa dilihat pada gambar 1 .

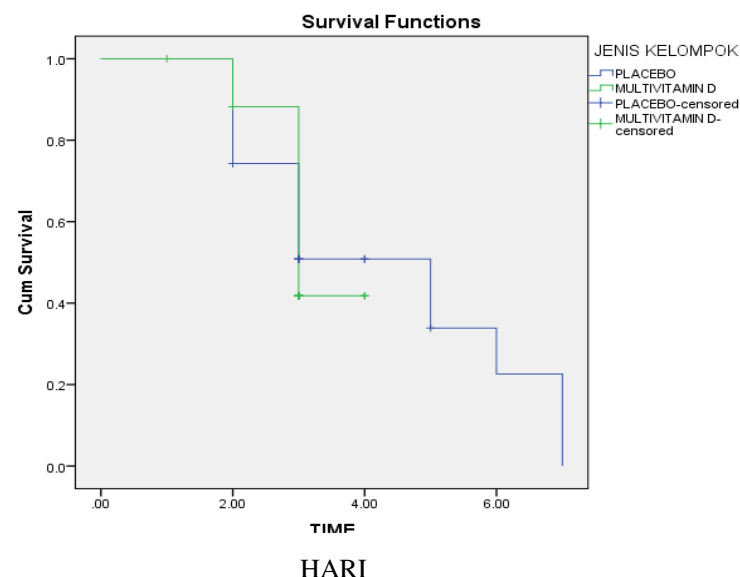

Gambar 1. Kaplan meier 
Pada gambar 1, dapat dilihat bahwa kurva Kaplan Meier pada hari ke 3 menunjukkan pasien yang mendapatkan terapi vitamin $D$ memiliki peluang tahan hidup lebih baik dibandingkan dengan pasien yang tidak mendapatkan vitamin D (plasebo). Hal ini bisa dilihat bahwa kurva hijau (kurva vitamin D) berada di bawah kurva biru (kurva plasebo). Hasil ini juga menjelaskan bahwa pemberian vitamin $D$ pada kasus anak yang menderita pneumonia memiliki peluang penurunan suhu tubuh yang lebih baik dibandingkan dengan pasien yang tidak mendapatkan terapi vitamin $D$ sebagai terapi tambahan. Hasil penelitian in berbeda dengan hasil penelitian dilakukan oleh Refrensi [8] pada pasien anak yang menderita pneumonia berat dan mendapatkan vitamin $D$ menjelaskan bahwa vitamin $\mathrm{D}$ tidak memperlihatkan manfaat pada lama waktu sembuh pasien Selain itu juga vitamin $D$ belum mampu memberikan durasi perawatan di rumah sakit yang lebih singkat dibandingkan dengan pasien yang tidak mendapatkan vitamin $D$.

Penelitian lainnya yang dilakukan oleh Refrensi [9] di salah satu Rumah Sakit di India, menunjukkan bahwa tidak ada perbedaan yang signifikan antara kedua kelompok perlakuan dalam perbaikan klinis demam. Kedua penelitian di atas menyimpulkan bahwa pemberian vitamin $D$ yang diberikan jangka pendek (5 hari) pada pneumonia tidak memberikan efek yang menguntungkan.

\section{KESIMPULAN}

Vitamin D memberikan peluang tahan hidup yang lebih baik terutama di hari ke tiga daripada yang tidak mendapatkan vitamin $D$ pada kasus pneumonia anak.

Saran: perlu dilakukan penelitian yang sama dengan dosis yang lebih besar dan dilakukan pengelompokkan tingkat keparahan penyakit pneumonia.

\section{UCAPAN TERIMA KASIH}

Penulis mengucapkan terimakasih banyak kepada responden, apoteker, dan perawat di Rumah Sakit PKU Muhammadyah Bantul Yogyakarta yang sudah membantu dan memfasilitasi penelitian ini sehingga peneliti mampu menyelesaikan penelitian ini dengan baik.

\section{DAFTAR PUSTAKA}

1. World Health Organization. 2014. Revised WHO classification and treatment of childhood pneumonia at health facilities Evidence summaries: new medicines.

2. Roomaney, R. A., Pillay-Van Wyk, V., Awotiwon, O. F., Dhansay, A., Groenewald, P., Joubert, J. D.,... Bradshaw, D. 2016. Epidemiology of lower respiratory infection and pneumonia in South Africa (1997-2015): A systematic review protocol. BMJ Open, 6(9).

3. Vos, T., Kyu, H. H., Pinho, C., Wagner, J. A., Brown, J. C., Bertozzi-Villa, A., Murray, C. J. L. 2016. Global and national burden of 
diseases and injuries among children and 53(11), 967-976.

adolescents between 1990 and 2013 findings from the global burden of disease 2013 study. JAMA Pediatrics, 170(3), 267287

4. McNally, J. D., Menon, K., Chakraborty, P., Fisher, L., Williams, K. A., Al-Dirbashi, O. Y., \& Doherty, D. R. 2012. The Association of Vitamin D Status With Pediatric Critical Illness. Pediatrics, 130(3), 429-436.

5. Sankar, J., Lotha, W., Ismail, J., Anubhuti, C., Meena, R. S., \& Sankar, M. J. 2016. Vitamin $\mathrm{D}$ deficiency and length of pediatric intensive care unit stay: a prospective observational study. Annals of Intensive Care, 6(1), 1-9.

6. Anwar, A., \& Dharmayanti, I. (2014). Pneumonia among Children Under Five Years of Age in Indonesia. Pneumonia Among Children Under Five Years of Age in Indonesia, 8(8), 359-365.

7. Dinkes Bantul. 2017. Profil Kesehatan Kabupaten Bantul Tahun 2017. Dinas Kesehatan Kabupaten Bantul.

8. Choudhary N, \& Piyush G. 2011. Vitamin D supplementation for severe pneumonia-A randomized controlled trial. Indian Pediatrics, 49(6), (449-454).

9. Gupta, P., Dewan, P., Shah, D., Sharma, N., Bedi, N., Kaur, I. R., Madhu, S. V. 2016. Vitamin D supplementation for treatment and prevention of pneumonia in under-five children: A randomized double-blind placebo controlled trial. Indian Pediatrics, 